\title{
A DISCOURSE ANALYSIS OF MATTHEW'S NATIVITY NARRATIVE
}

\author{
William Varner
}

\begin{abstract}
Summary
Discourse analysis (DA) as a discipline of studying written texts has been utilised in literary circles for over fifty years. Its emergence into biblical studies can be traced to the decade of the 1960s and it has been utilised mainly by scholars trained in descriptive linguistics. Although its terminology is still fluid, there is a common core methodology that warrants serious consideration that DA should be employed by NT scholars. Defining it simply as 'grammar above the level of the sentence', the author shows how DA's tools can be employed to indicate how Matthew structured his Nativity narrative to convey his overall message. Scholars should not allow the distinctive terminology of DA to keep them from utilising it as a tool to discern authorial intent in the biblical texts.
\end{abstract}

\section{Introduction}

In his excellent Greek grammar, Daniel Wallace explains why he omitted any discussion of discourse analysis (DA) from his book with this statement: 'DA is still in its infant stages of development, in which the methods, terminology, and results tend to be unstable and overly subjective.'

Wallace is accurate in describing the emerging nature of DA, although 'infant stages' may be an inaccurate expression to describe a discipline that has been utilised in biblical studies for well over a

1 Daniel B. Wallace, Greek Grammar Beyond the Basics (Grand Rapids: Zondervan Publishing House, 1996): xv. Based on personal conversation with Wallace, I believe that his attitude toward DA could still be described as 'open', but awaiting its development into a more mature stage before he issues a final opinion on it. 
quarter of a century. ${ }^{2}$ Furthermore, at least two intermediate level Greek grammars by Stanley Porter and Richard Young which seek to define and describe DA were published just prior to Wallace's grammar. ${ }^{3}$ These grammars attempt to integrate DA with traditional syntactic categories as well as to include linguistic insights from such related fields as semantics, speech-act theory and rhetorical analysis. Also, a number of collaborative monographs have been issued in the last fifteen years that have sought to develop the theoretical basis of DA as well as the application of it to specific biblical texts. ${ }^{4}$ Furthermore, scholars in the Summer Institute of Linguistics and NT scholars in South Africa have issued an abundance of articles and monographs on DA, particularly in their focused journals. ${ }^{5}$

The current 'chronographer' of DA has been Stanley Porter, who has sought to keep his readers abreast of developments in the field, and has himself contributed to those developments. In a seminal article for anyone desiring to understand the development of DA, Porter traces the genesis of the discipline to literary circles of the $1950 \mathrm{~s}$ and $60 \mathrm{~s}$. He then describes four current 'schools' of DA that have developed in biblical studies over the last three decades. ${ }^{6}$ In noting the widespread influence of the 'South African' school exemplified by the theoretical

2 A brief history of DA with documentation of these early efforts can be found in Stanley Porter, 'Discourse Analysis and New Testament Studies: An Introductory Survey', Discourse Analysis and Other Topics in Biblical Greek, ed. S. E. Porter and D. A. Carson (Sheffield: Sheffield Academic Press, 1995): 14-35.

3 Stanley Porter, Idioms of the Greek New Testament 2nd ed. (Sheffield: Sheffield Academic Press, 1994) and Richard Young, Intermediate NT Greek: A Linguistic and Exegetical Approach (Nashville: Broadman and Holman, 1994).

4 See, e.g., D. A. Black with K. Barnwell and S. Levinsohn, eds., Linguistics and NT Interpretation: Essays in Discourse Analysis (Nashville: Broadman, 1992); S. Levinsohn, Features of NT Greek 2nd ed. (Dallas: SIL International, 2000); Porter and Carson, eds., Discourse Analysis and Other Topics in Biblical Greek; S. E. Porter and J. T. Reed, eds., Discourse Analysis and the NT (Sheffield: Sheffield Academic Press, 1999).

5 See, e.g., the early work by K. Barnwell, Discourse Considerations in Translating the Word of God (Grand Rapids: Zondervan, 1974). Most of the articles, however, have been in journals that are not readily noticed by many scholars in NT. See for example, two journals associated with the Summer Institute of Linguistics: Bible Translator published since 1950 and Journal for Translation and Textlinguistics (formerly OPTAT) published since 1987, as well as two journals associated with NT scholars in South Africa: Neotestamentica, published since 1967 and Scriptura published since 1976. Much of this work on DA, therefore, is open to the criticism of being 'insular'. Also comparatively few articles on DA have appeared in the major journals associated with NT studies.

6 Porter, 'Discourse Analysis and New Testament Studies', 14-35. 
and applied labors of J. P. Louw and Eugene Nida, Porter calls it 'the most well-coordinated school of thought in discourse analysis' ${ }^{7}$ While the differences between these schools are significant to their adherents, there is still a common core of concerns and methods that unites them all. Therefore, the variations in the details of their approaches should not be portrayed as an inherent weakness of an immature discipline. What, then, is that common core methodology?

I have often expressed to my students a frustration in arriving at a concise definition of DA. Sometimes I have taken refuge in the statement that 'discourse analysis is better described than defined.' Even if that is true, it does not mean that advocates of DA have not attempted a definition. Different proponents of DA oftentimes have their own nuanced definition. At its most basic level, as I see it, DA deals with grammatical and semantic functions as they affect meaning above the level of the sentence. It differs from traditional grammars which deal almost exclusively with the function of words in a clause or a sentence. I find myself in essential agreement with Steven Levinsohn's definition.

Discourse analysis is an analysis of language features that draws its explanations, not from the sentence or word (i.e., the factors involved are not syntactic or morphological), but extrasententially (from the linguistic and wider context). In the case of written material, explanations are drawn mainly, though by no means exclusively, from the previous sentences of the text. ${ }^{8}$

It could also be said that DA is more holistic in its approach to language while traditional grammar is more atomistic. DA is also not content to simply identify the function of a word or a grammatical construction inside the sentence. DA recognises that a word or construction possibly may also serve a role as a discourse marker which conveys meaning through the text as a whole. This function of the discourse marker will be illustrated later in this article by a discourse analysis of the four pericopes that comprise Matthew's

7 Porter, 'Discourse Analysis and New Testament Studies'; or Porter, Idioms of the Greek New Testament, 33. See, e.g., J. P. Louw, 'Discourse Analysis and the Greek NT', Bible Translator 24 (1973): 101-18; Semantics of NT Greek (Philadelphia: Fortress Press, 1982); E. A. Nida, J. P. Louw, A. Synam and W. J. Cronje, Style and Discourse, with Special Reference to the Text of the Greek NT (Roggebai: Bible Society, 1983).

8 Steven Levinsohn, Discourse Features of New Testament Greek: A Coursebook on the Information Structure of NT Greek (Dallas: Summer Institute of Linguistics, 2000): viii. 
account of the Nativity narrative from 1:18 to 2:23. Particularly, the analysis will discuss the role of the Genitive Absolute participles as discourse markers introducing each pericope.

Proponents of DA, in the opinion of this writer, are not seeking to replace traditional grammar with 'DA grammar'. They are seeking to add to our understanding of traditional grammar by calling attention to larger features in a text than those limited to the sentence. DA advocates, for example, do not discount the describing of different case uses and the detailed functions of the infinitive and participle. But DA insists that meaning is not conveyed by those grammatical constructions exclusively within the sentence. Meaning is conveyed through sentences that are part of a larger text which is called a discourse. While it is true that a sentence is not simply the sum of its parts, it likewise is true that a text/discourse is not simply the sum of its sentences. In some ways DA is simply an application of the timehonoured importance of context expressed in linguistic terms.

Practitioners of DA are also not content to only describe grammatical functions; they affirm that the choice by an author of certain grammatical uses implies meaning. In other words, the author of a text has a purpose in choosing a word or a form that often will imply more than just stylistic variation. To the extent to which it can be ascertained, the discourse analyst seeks to discover that intent of the author. It is also recognised that confirming evidence for conclusions about authorial intent must be illustrated or the analyst will be guilty of simply imposing his or her own intent on the text. The degree to which I or any discourse analyst successfully uncovers that meaning of a discourse through its evident grammatical and structural features will have to be judged by the precision of the analysis and the other supporting factors of grammar, semantics, and context.

It is best now to attempt a modest effort at discourse analysis in action rather than to make any further attempt at defining it and defending its legitimacy. Porter and Reed have written that discourse analysis 'no matter what model is being used, is often at its best when it is reading texts rather than theorising about its method. ${ }^{9}$ It is to such an effort at applying discourse principles to Matthew's Nativity Narrative that we now turn.

9 Porter and Reed, Discourse Analysis and the NT, 16. 


\section{The Structure of Matthew's Gospel}

Scholars over the past seventy-five years have thoroughly debated the question of how Matthew structured his gospel. Most scholars today adopt either B. W. Bacon's suggestion of a fivefold structure plus prologue and epilogue or Jack Kingsbury's proposal of a threefold structure. ${ }^{10}$ Bacon noted the sentence that is variously repeated at the

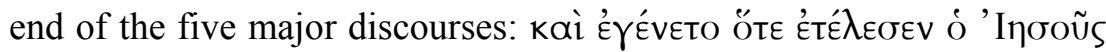
toùs $\lambda$ órous toútous ('and when Jesus finished these words ...' in $7: 28 ; 11: 1 ; 13: 53 ; 19: 1$; and 26:1, with slight variations). Each of these five discourses is preceded by a narrative section, although some debate has occurred over exactly where these narrative blocks begin and end. Bacon further suggested that Matthew was composed by a Christian Rabbi who intended his Gospel to portray a new Pentateuch.

On the other hand, Kingsbury sees the twice repeated statement,

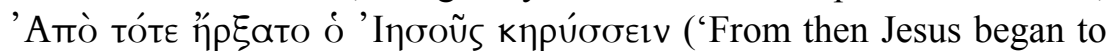

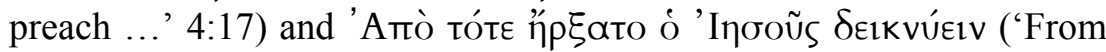
then Jesus began to show ...' 16:21) as comprising the two hinges on which the book turns. Thus he suggests an outline of three sections: (1) 'The Person of Jesus Messiah' (1:1-4:16); (2) 'The Proclamation of Jesus Messiah' (4:17-16:20); and (3) 'The Suffering, Death and Resurrection of Jesus Messiah' (16:21-28:20). ${ }^{11}$

While Kingsbury has had a number of defenders and modifiers, most scholars today adopt a structure along the lines of Bacon's fivefold proposal. ${ }^{12}$ On the other hand, Robert Gundry, while favouring the fivefold arrangement, sees the Gospel as 'structurally mixed'. ${ }^{13}$ In their magisterial commentary, Davies and Allison have sympathy for

10 Benjamin W. Bacon, Studies in Matthew (London: Constable, 1930); Jack D. Kingsbury, Matthew: Structure, Christology, Kingdom (Philadelphia: Fortress Press, 1975).

11 Kingsbury has elaborated and refined this view of Matthew's structure in over a dozen journal articles both before and after his 1975 volume.

12 For a defense of a modified threefold division, see David R. Bauer, The Structure of Matthew's Gospel: A Study in Literary Design (Sheffield: Sheffield Academic Press, 1988). For a defence of a modified fivefold division, see Christopher R. Smith, 'Literary Evidences of a Fivefold Structure in the Gospel of Matthew', NTS 43 (1997): 540-51.

13 Robert Gundry, Matthew: A Commentary on His Handbook for a Mixed Church under Persecution, 2nd ed. (Grand Rapids: Eerdmans, 1994): 11. 
both the fivefold and the mixed division, although they doubt anyone's ability to successfully unlock the structure. ${ }^{14}$

This writer also thinks that Bacon's view has great merit and that the arguments for a fivefold division to the Gospel are structurally convincing. Whatever be the final word on the book's overall structure, however, the opening chapters of Matthew 1 and 2 still comprise the extended prologue of the entire work, while 26-28 form the extended epilogue. ${ }^{15}$ The following discourse analysis will, I believe, confirm the unique role of chapters one and two as the prologue to the Gospel.

\section{Analysis of Matthew's Nativity Narrative}

The title in 1:1 along with the genealogy in 1:2-17 are separate literary units from the narrative in 1:18-2:23, although they certainly prepare the reader for that narrative. The end of this pericope in 1:17 is connected with the beginning of the next pericope in 1:18 through the shared word Xpıбтоũ, a literary 'hook' in linguistic terminology. Its different genre and literary features, however, are so distinct from what follows that it demands a separate treatment. Therefore, we will direct our attention to the particular discourse features of the passage that follows the genealogy in Matt. 1:18-2:23.

\subsection{The Discourse Role of the Genitive Absolute Participle}

The entire section from 1:18 to 2:23 contains a total of fifty participles in thirty-one verses. Of these, eight function adjectivally, while fortytwo function adverbially. These adverbial participles carry the flow of the narrative, many in an 'Attendant Circumstance' function. Of these forty-two participles, only five are in the Genitive Absolute construction and each of them appear at the beginning of a pericope.

14 W. D. Davies and Dale Allison, The Gospel According to Saint Matthew, Vol. 1 (Edinburgh: T\&T Clark, 1988): 61.

15 In Kingsbury's approach, the distinctive nature of chapters 1 and 2 seems to be deemphasised as they are subsumed under his first section $(1: 1-4: 16)$. Also, the two

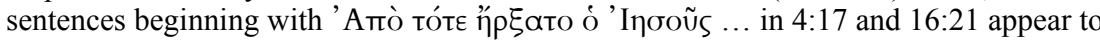
serve more as significant turning points in Jesus' ministry rather than as structural markers in Matthew's Gospel. It should also be noted that that some scholars do not see any attempt by Matthew to consciously structure his gospel by inherent linguistic indicators. Nolland is representative of these writers in that he presents Matthew's material as twenty-two successive topics in the life of the Lord. John Nolland, The Gospel of Matthew (NIGTC; Grand Rapids: Eerdmans, 2005): 44-62. 
The following chart illustrates this and also sets forth the common features in the pericopes which will be highlighted in the ensuing analysis. The reader is encouraged to refer back to this chart as the discourse features are mentioned

\begin{tabular}{|c|c|c|c|}
\hline $1: 18-25$ & $2: 1-12$ & 2:13-18 & $2: 19-23$ \\
\hline $1: 20$ & $2: 1$ & $2: 13$ & $2: 19$ \\
\hline 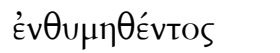 & $\gamma \varepsilon v \vee \eta \theta$ Évtos & 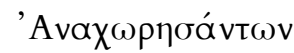 & T \\
\hline $1: 20$ & $2: 1$ & $2: 13$ & $2: 19$ \\
\hline 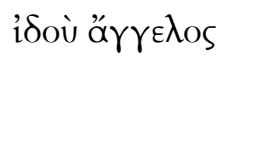 & 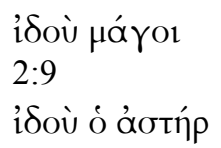 & 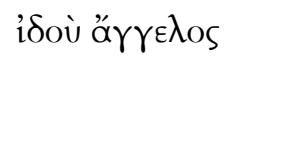 & 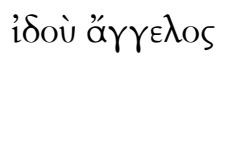 \\
\hline $1: 20$ & $2: 7$ & $2: 13$ & $2: 19$ \\
\hline 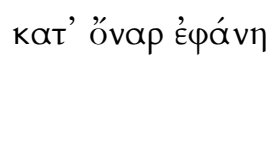 & $\begin{array}{l}\text { paıvopévou } \\
2: 12 \\
\text { kat' óvap }\end{array}$ & $\begin{array}{l}\text { paívetal kat' } \\
\text { óvap }\end{array}$ & $\begin{array}{l}\text { paívetal kat' } \\
\text { óvap }\end{array}$ \\
\hline 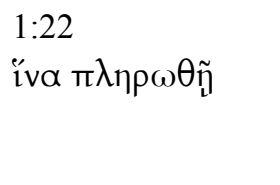 & 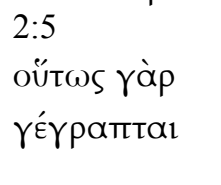 & 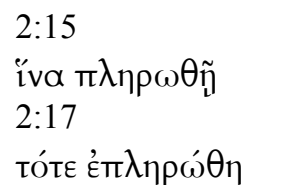 & $\begin{array}{l}2: 23 \\
\text { ö } \pi \omega \varsigma \pi \lambda \eta p \omega \theta \tilde{\eta}\end{array}$ \\
\hline $1: 22$ & $2: 5$ & $2: 15$ & $2: 23$ \\
\hline 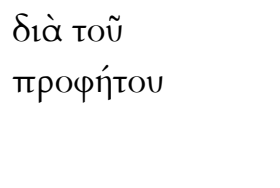 & 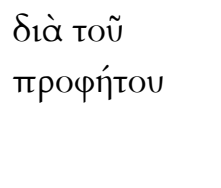 & 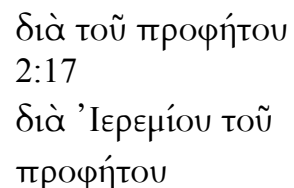 & $\begin{array}{l}\delta i \grave{\alpha} \tau \tilde{\omega} v \\
\pi \rho о \varphi \eta \tau \tilde{\omega} v\end{array}$ \\
\hline
\end{tabular}

Each of the four pericopes follows a shared narrative and linguistic pattern. First, each section is introduced by a Genitive Absolute (GA) Aorist Participle: '̇v $\theta$ un $\theta$ Évtos ('while he was thinking') in 1:20;

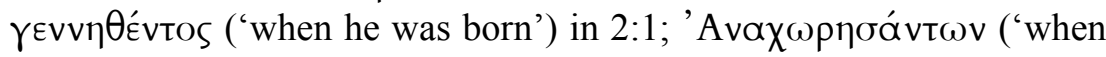

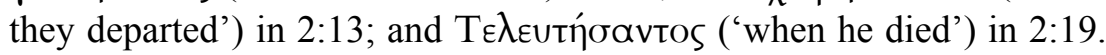

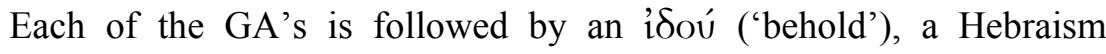
recalling the Hebrew דִִּ which appears eighty-three times in Genesis

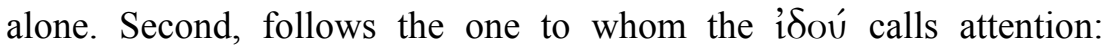

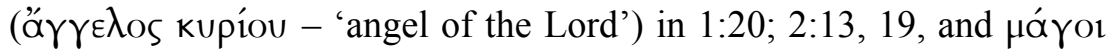
'wise men' in 2:1. Dale Allison, however, makes a very persuasive case that Matthew desires us to see the 'star' in this section as referring to an angel. ${ }^{16}$ Thus, it is important to note that Matt. 2:9 repeats the

16 Dale C. Allison, 'The Magi's Angel' in Studies in Matthew: Interpretation Past and Present (Grand Rapids: Baker Academic, 2005): 17-42. 
pattern with íov̀ ò ơotíp ('behold the star'). This interpretation then

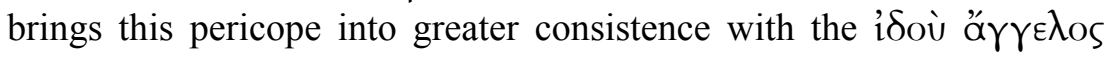

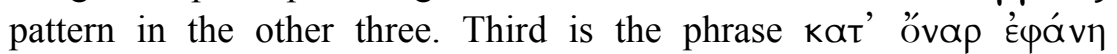
('appeared in a dream'), although that word order and tense in 1:20 differ in 2:13 and 2:19 (paívetal kat' óvap). This clause, however, does not appear in the second pericope concerning Magi. However, it is often overlooked that the Magi were later warned kat' óvap ('in a dream') in 2:12 and the same verb does appear in a participial form referring to the star (an angel) in 2:7 ( paıvopévou - 'appearing'). Thus Joseph received divine direction three times from the appearing of an angel and the Magi receive divine direction from the appearing of an angel under the figure of a star. Fourth, in each pericope there is a 'formula quotation' of an OT scripture. There is also variation with these formulae. The same expression iv $\alpha \pi \lambda \rho \omega \theta \tilde{\eta} \ldots$. $\delta i \grave{\alpha}$ тoũ трофи́то ('that it may be fulfilled ... through the prophet') is in both

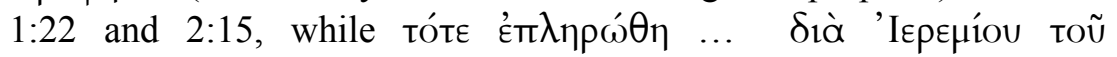
трофи́то ('then was fulfilled ... through Jeremiah the prophet') is in $2: 17$. This is also the second formula quotation in that third section and the only one mentioning the prophet's name. Finally, in 2:23 we read ö $\pi \omega \varsigma \pi \lambda \eta \rho \omega \theta \tilde{\eta} \ldots \delta$. . $\grave{\alpha} \tau \tilde{\omega} v \pi \rho о \varphi \eta \tau \tilde{\omega} v$ ('that it may be fulfilled ... through the prophets'). We will return to examine most of these slight variations later in our discussion. ${ }^{17}$

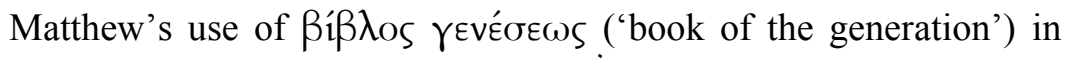
1:1 and 18 echoes the OT 'toledot' (תוֹלְדוֹת) markers of Gen. 2:4 and 5:1. The LXX utilises Matthew's Greek expression in these two passages. ${ }^{18}$ There are actually two Genitive Pariciples at the beginning of the first pericope $(1: 18-25)$, unlike the last three. However, the initial

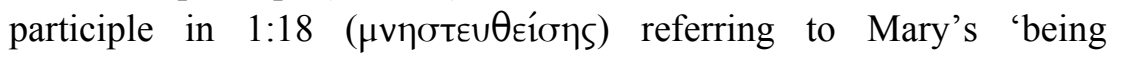
betrothed' is one of those occurrences when the GA's noun referent

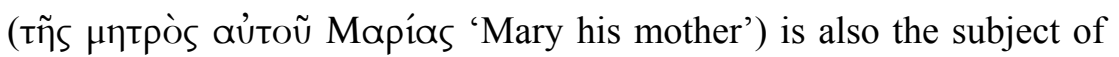

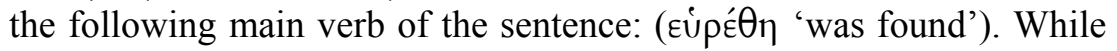
this 'non-absolute' characteristic is not unknown with GAs, it is extremely rare among its fifty-two occurrences in Matthew (the only other non absolute occurrence is in 9:32). The second GA is in 1:20, where the subject is Joseph but where he is not the subject of the main

17 Two other repeated linguistic phenomena appear in three of the sections:

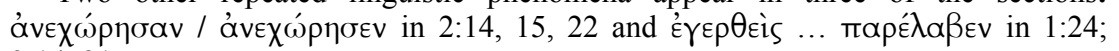
2:14, 21.

18 Allison, 'Matthew's First Two Words' in Studies in Matthew, 157-72. 


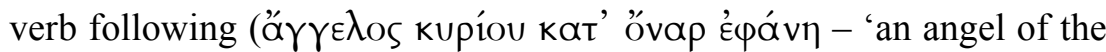
Lord appeared in a dream'). This is the 'normal' way in which a GA functions, especially in Matthew. Since the primary subject of the section is Joseph, who is introduced in 1:19, and since the later sections also deal only with him by name, a case can be made that the first section actually begins in 1:20 with 1:18 forming a bridge from the end of the genealogy ending in 1:17 to Joseph's introduction in 1:19 and the beginning of the 'GA plus iooú pattern' in 1:20. This connecting function of $1: 18$, with its 'irregular' $\mathrm{GA}$, is strengthened by the 'hookword' Xpıбтoũ which links 1:17 to 1:18. ${ }^{19}$ In 1:20, therefore, the common literary pattern described above then begins and continues to be repeated in the later sections.

We conclude that the GA that introduces an íov clause was intended by Matthew to introduce each successive pericope in the Infancy Narrative. These GA aorist participles also convey the 'temporal' adverbial idea as they do about $90 \%$ of the time. ${ }^{20}$ In addition to its adverbial idea, however, the participle serves a discourse function to mark the beginning of a new pericope in the overall section. This discourse marking can also be seen in the seven other instances of

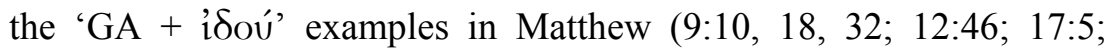
$26: 47 ; 28: 11)$. In such cases, these words introduce either a new pericope or a subsection of a larger pericope when a new person or thing is introduced in the account (e.g. 17:5). ${ }^{21}$ This discourse function

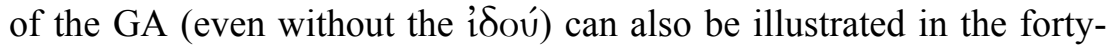
one other occurrences of this form in Matthew.22 Other NT authors

\footnotetext{
19 The use of 'hookwords' as a discourse feature is developed by George Guthrie in The Structure of Hebrews: A Text-Linguistic Analysis (Grand Rapids: Baker Book House, 1998): 12-14, 94-111. Guthrie illustrates effectively the author's use of these hookwords to staple together the seams of that discourse. He draws on the work of Vaganay and Vanhoye. In addition to 1:17/1:18, Matthew's use of a common 'hookword' to staple together the successive pericopes in our text can be seen with the

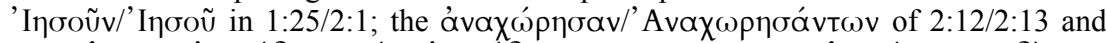

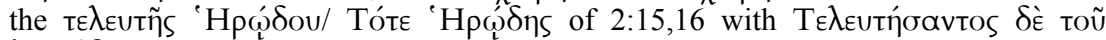

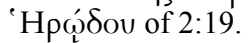

20 Wallace, Greek Grammar Beyond the Basics, 655.

21 The only other occurrence of this construction is in Luke 22:47. Interestingly, this is a synoptic parallel to Matt. 26:47, mentioned above.

22 It is overly burdensome to list these forty-one other occurrences but a simple search done in a grammatical concordance in one of the standard programs (BibleWorks or Accordance) will illustrate this 'new paragraph' or subsection function very easily.
} 
utilise this discourse function of the GA, particularly those writing in the narrative genre. ${ }^{23}$

Each of the standard scholarly grammars discusses the syntactical function of the GA. However, an examination of the treatment of the GA in these grammars reveals no mention by them of a discourse function above the level of the sentence. ${ }^{24}$ This is undoubtedly due to the fact that the grammarians are committed to the idea that the discussion of Greek syntax should be limited to the clause and sentence. However, in his previously mentioned intermediate grammar, Richard Young does briefly discuss the role of the GA beyond the sentence and even mentions that in Matt. 2:13 the GA of time marks a new paragraph. ${ }^{25}$ In his intermediate grammar, Stanley Porter, while explaining the syntax of the GA within the sentence, surprisingly does not mention any discourse role that the GA might serve above the level of the sentence. ${ }^{26}$ Obviously, more work needs to be done in this area of extra-sentential grammar as it relates to the GA. Happily, some recent commentators have taken note of the structural role of the GAs in Matthew one and two even if many of the standard grammars have been reluctant to do so. ${ }^{27}$

\subsection{The Discourse Role of the Historic Present}

Much work has been done in recent years on the issue of Verbal Aspect vis-à-vis the time-honoured function of Aktionsart in understanding Greek tense usage. Fanning and Porter have contributed significant monographs on the subject while individual chapters and articles have

\footnotetext{
23 Levinsohn describes the discourse role of the GA as setting the scene for the introduction of a new participant (183) and for highlighting the introduction of participants who will perform significant actions (197). He also cites this 'boundary marking' function in Matt. 2:13 and 2:19 (202).

24 Wallace, Greek Grammar Beyond the Basics, 654-55; F. Blass and A. Debrunner, A Greek Grammar of the New Testament and Other Early Christian Literature, tr. and ed. Robert Funk (Chicago: University of Chicago Press, 1961): section 423, 218-19; A. T. Robertson, A Grammar of the Greek New Testament in the Light of Historical Research (New York: Hodder and Stoughton, 1919): 1131-32; G. B. Winer, A Treatise on the Grammar of the New Testament, 3rd ed. (Eugene, OR: Wipf and Stock, 1997): 242-43; J. H. Moulton and Nigel Turner, A Grammar of New Testament Greek (Edinburgh: T\&T Clark, 1963): III, 322-23.

25 Young, Intermediate NT Greek, 159. '[The GA] also seems to have a discourse function at the beginning of paragraphs or subparagraphs to indicate a change in setting. This is especially true in narrative.'

26 Porter, Idioms, 182-84.

27 Davies and Allison, Saint Matthew, 198, 259; Nolland, Matthew, 96, 108.
} 
continued the discussion. ${ }^{28}$ It is not within the purpose and constraints of this article to review or to mediate that important debate. Wallace has offered a balanced handling of the issues in his grammar. ${ }^{29}$ What I would offer is a glimpse of the role of the so-called 'Historic Present' as it has been traditionally defined and enquire whether there may be a further role that it plays in the NT. We will then seek to illustrate its role in Matthew's narrative, especially in one section of his Infancy Narrative (Matthew 2).

A standard classic on verb syntax succinctly describes the role of the Historical Present (HP) as follows: 'The Present Indicative is used to describe vividly a past event in the presence of which the speaker conceives himself to be.' ${ }^{30}$ This general definition is more or less reiterated in the other standard grammars. The additional matters mentioned are that when the author uses the HP he has shifted from the normal tense for narration, the aorist (to which he returns after the HP), and that the Aktionsart (punctiliar action), remains the same in the HP. ${ }^{31}$

In light of this reluctance by the old classical grammars (Winer, Robertson, and Blass/Debrunner) to indicate any discourse function for $\mathrm{HP}$, it is interesting to note the discussion of the HP by Turner in the third volume of the Moulton-Howard-Turner trilogy. While discussing the nature of Aktionsart and tense (that they do not match in the HP), Turner has the following citation mentioning the work of an older grammarian.

It (the HP) occurs about 337 times in LXX, of which 232 are in 1-4 Kms ... Here, according to Thackeray (Schweich Lectures, p. 21), it introduces a new scene in dramatic narrative, especially a new character or change of locality or a turning-point... 'The main function is this, I maintain, to introduce a date, a new scene, a new character, occasionally a new speaker; in other words, a fresh paragraph in the narrative.'... Thackeray suggested that the presents in Mark (except $\lambda \epsilon^{\varepsilon} \gamma \varepsilon 1$ ) were used in a similar way for new scenes and characters (p. 22). 'They generally

28 Buist Fanning, Verbal Aspect in New Testament Greek (Oxford: Clarendon, 1990); S. E. Porter, Verbal Aspect in the Greek of the New Testament, with Reference to Tense and Mood (New York: Peter Lang, 1989).

29 Wallace, Greek Grammar Beyond the Basics, xiv, 2, 3, 499-512.

30 Ernest DeWitt Burton, Syntax of the Mood and Tenses in NT Greek (Grand Rapids: Kregel Publications, 1976): 9.

31 F. Blass and A. Debrunner, A Greek Grammar of the New Testament and Other Early Christian Literature, tr. and ed. R. Funk (Chicago: University of Chicago Press, 1961): 167; Robertson, A Grammar of the Greek New Testament in the Light of Historical Research, 866-69; Winer, A Treatise on the Grammar of the New Testament, 282. 
coincide with chapter-openings in the capitulary system in Codex Alexandrinus. ${ }^{32}$ (italics mine)

While Turner seems to quote Thackeray approvingly, he does not follow up his quotation with any further discussion of this function of the HP in the NT. While Wallace's discussion of the HP does not affirm any 'Aktionsart/punctiliar' function, he adds that the probable intent of the author in using the HP was 'to show the prominence of the events following'. 33 These last two authors (Turner and Wallace) certainly evidence a measured attempt at indicating a possible extrasentential function of the HP.

It has remained for recent grammarians to assert and exemplify a discourse function of the HP. Porter first takes a cautious position on its discourse function due to a number of instances in the NT where it does not indicate change, yet later mentions its use by Mark to indicate a 'discourse boundary' or beginning of a new pericope. ${ }^{34}$ Young declares rather emphatically:

The historical present is normally interpreted rhetorically, that is, to vividly bring a past event before the reader. Although there is some merit in the traditional understanding, historical presents (non- $\left.\lambda \varepsilon^{\prime} \gamma \omega\right)$ are better understood as having a discourse function of giving prominence to the beginning of a paragraph, to the introduction of new participants, or to a change in setting. ${ }^{35}$

Levinsohn discusses the role of the HP in a number of locations in the second edition of his Discourse Features volume and concludes, 'Since non-speech HP's commonly occur at the beginning of a subsection, switches from an aorist or imperfect to a non-speech HP may provide supporting evidence of a boundary.' 36

Stephanie Black, after a careful analysis of the occurrences of the HP, concludes:

Matthew uses the historic present in a manner best explained by an aspectual approach to verb tense-forms. He alternates the historic present

32 Moulton and Turner, Grammar of New Testament Greek, III, 61-62.

33 Wallace, Greek Grammar Beyond the Basics, 526. See also Porter's Verbal Aspect in the Greek of the New Testament, 134-36.

34 Porter, Verbal Aspect, 31, 301.

35 Young, Intermediate NT Greek, 110.

36 Levinsohn, Discourse Features, 280. 
with other tense-forms to help create the narrative's structure and make his storytelling more engaging to his readers. ${ }^{37}$

With this in mind, what can be said about the HP in Matthew's Nativity

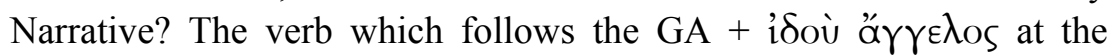
beginning of three of the pericopes $(1: 20 ; 2: 13,19)$ is the indicative of paivw ('appear') accompanied by the adjunct phrase kat' óva $\rho$ ('in a

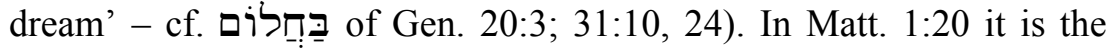

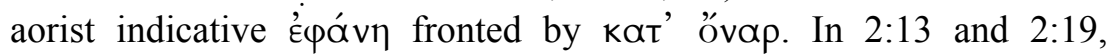
however, Matthew employs the HP paívetal followed by kat' óvap. These variations raise two questions. First, if the function of the HP is only to add vividness to the account, why does Matthew wish to add such vividness at 2:13 and 19 but not at 1:20? Second, is the fronting of kat' óvap in 1:20 simply a matter of stylistic variation or is there some reason for the difference in the word order with 2:13 and 19?

There is no question that the HP adds vividness to an account, be it here in Matthew or in its many appearances in Mark. ${ }^{38}$ The use of the HP here in Matt. 2:13 and 2:19, however, serves an additional function of indicating another pericope that deals with an already introduced character in the overall account - Joseph - to whom in 1:20 'an angel

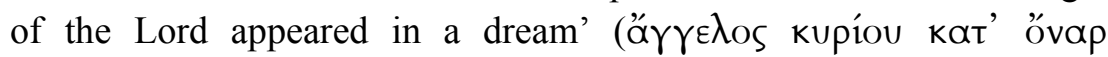
Éq́a $v \eta)$. The aorist tense in this verse is explained by its being the unmarked (i.e. the normally expected) tense in narrative, especially when introducing a character. It also is referred to by Porter as the background function of that tense in narrative. When that same character (Joseph) is reintroduced in the account in the same manner as before, the HP marks that reintroduction - in addition to adding vividness and serving Porter's foreground function. ${ }^{39}$ Furthermore, the fronting of kat' óvap indicates a marked order, adding prominence to the dream theme as well as contributing, along with the previous words, to further marking the beginning of a new pericope. When that phrase is repeated in 2:13 and 2:19, however, there is no need to indicate prominence so it follows the verb in its normal, unmarked position, and serves to continue the 'discourse' already begun in 1:20.

\footnotetext{
37 Stephanie Black, 'The Historic Present in Matthew: Beyond Speech Margins' in Discourse Analysis in the NT, eds. Porter and Reed, 126.

38 J. C. Hawkins lists seventy-eight HPs in Matthew, 151 in Mark and only four to six in Luke. Horae Synopticae (Grand Rapids: Baker Book House, 1968): 144-49.

39 Porter, Idioms, 23.
} 
Thus, the HPs in 2:13 and 2:19 do serve a function both within the sentence and above the level of the sentence. ${ }^{40}$

The second pericope, while introducing the characters with the GA + íoú $(2: 1)$ as in the other pericopes, does not call attention to an

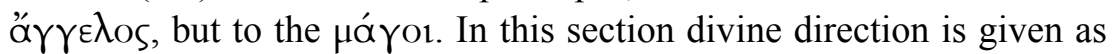

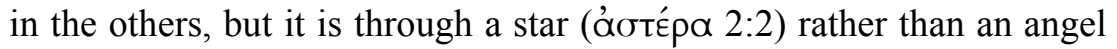

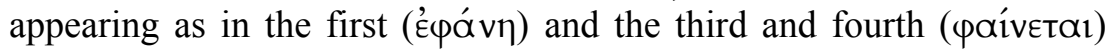
pericopes. But if Allison is correct in seeing this 'star' as an angelic reference (footnote 16), it would indicate a Matthean effort at consistency between the patterns of the other pericopes. Thus, when Matthew reports the Magi's reference to the star they had seen appear, the word they use is the present participle of paiv $\omega$ ( paıvopévou 2:7). The angel appeared to give direction to the person (Joseph) addressed by idoú in the three other sections, while in this section the star (an angel) appears to give direction to the main persons (the Magi) addressed by the íoú. How could this just be coincidental?

\subsection{The Discourse Role of tóte}

The adverbial conjunction tótє is distinctively Matthean. The word appears ninety times in Matthew while only six times in Mark and fifteen times in Luke. In narrative sections, however, the ratio is even more 'Matthean' (60/0/2). ${ }^{41}$ Throughout Matthew, especially in its sentence-initial position, тótє is a marker of continuity. ${ }^{42}$ Danker

40 Black supports this idea in her article and also points out the significance of the HP in the temptation account in 4:1-11. Matthew records the Tempter addressing Jesus in the first temptation in the aorist tense (

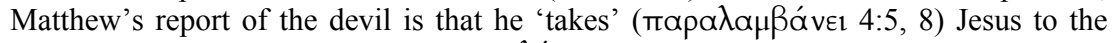
pinnacle and the mountain. He 'says' ( $\lambda \varepsilon^{\prime} \gamma \varepsilon$ 4:6) to him the second temptation and

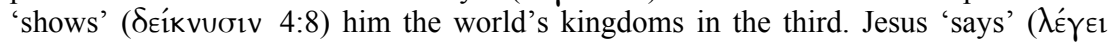
4:10) to him his third response and after the ordeal, Matthew adds that then the devil 'leaves' ('áínoıv 4:11). In his account Matthew thus introduces the participants by aorists and describes in aorists how they initially spoke. Their subsequent remarks, however, he introduces by HPs. These HPs do add vividness to Matthew's account, but also serve as discourse markers of the segments while foregrounding the action in much the same way as he employed them in 2:13 and 2:19. Black does not mention the foregrounding action of the present tense, which is Porter's terminology. Black, 'The Historic Present in Matthew: Beyond Speech Margins' in Discourse Analysis in the NT, 129-35.

41 Hawkins, Horae Synopticae, 8.

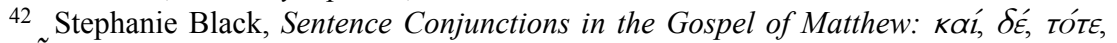
ouvv, and Asyndeton in Narrative Discourse (Sheffield: Sheffield Academic Press, 2002): 221. See her entire chapter (218-53) for a thorough analysis of this conjunction in Matthew. 
defines its meaning in a sentence initial position as: 'to introduce that which follows in time' then, thereupon. ${ }^{43}$

In the Nativity narrative it appears three times $(2: 7,16,17)$. In 2:17 it functions differently from the two earlier appearances. Danker defines it in this verse as meaning at that time, of the past then ${ }^{44} \mathrm{It}$ introduces one of the 'formula quotations' in 2:17 and its role will be mentioned in the next section when we briefly examine each of those five 'formula quotations'.

The other two earlier occurrences of тóte are quite similar both in form and function. First, they appear at key transitional points in the second and third sections to introduce Herod's response to events that have just taken place in relation to actions of the Magi. In 2:7, 8a: 'Then (то́тє) Herod secretly called the Magi and inquired from them as to when the star appeared, and sent them to Bethlehem and said, "Go and search diligently for the child".' In 2:16: 'Then (то́тє) Herod, when he saw that he was mocked by the Magi, was very angry and sent and destroyed all the male children who were in Bethlehem and in all that region who were two years old or under, according to the time that he had inquired from the wise men.'

Although both sentences describe actions different in purpose and outcome, they share many linguistic features. (1) Both have a sentenceinitial tótє followed by 'Herod' and a participle with the Magi as the object of the participle. (2) Both verses contain the verb 'enquired'

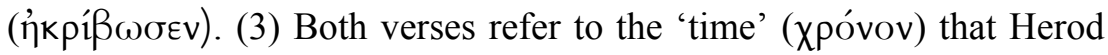
enquired of the Magi. (4) In both sentences, Herod 'sends' someone to Bethlehem. Interestingly, the word used in 2:8 about sending the Magi to enquire is the verb $\pi \dot{\varepsilon} \mu \pi \omega$, while the verb used in 2:16 of sending (soldiers?) to kill is the verb ámooté $\lambda \lambda \omega{ }^{45}$

43 Frederick Danker, ed., A Greek-English Lexicon of the New Testament and Other Early Christian Literature (Chicago: University of Chicago Press, 2000): 1012.

44 Danker, Greek-English Lexicon, 1012.

45 Most commentators make no mention of any significance in the different words for 'send'. It is easy at times to commit the 'synonym fallacy' and see differences between such words when there are none in their actual usage. Matthew's style of careful linguistic articulation may, however, indicate an intended difference. Could ómобт́́ $\lambda \lambda \omega$ imply a greater force of authority behind the sending than $\pi \dot{\varepsilon} \mu \pi \omega$ ? $B D A G$ defines the use of ámoбré $\lambda \lambda \omega$ in this verse as being used with other verbs to have something done or, more specifically he had (them) killed (121). Custer summarises his conclusion about these words, "The word ámooté $\lambda \lambda \omega$ denotes "I send with a commission" or "I send officially." $\pi \varepsilon ́ \mu \pi \omega$ is a general word for "I send." In some contexts it certainly means "I send officially," but by no means always; the context must decide.” Treasury of NT Synonyms (Greenville: BJU Press, 1975): 116. 
The similarity of the sentences stands in stark contrast to their differences regarding Herod's stated purpose in the sending. In 2:7, 8

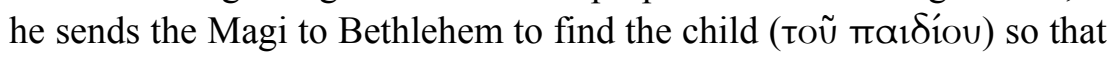
he may also worship him. In 2:16, he sends to Bethlehem to destroy all

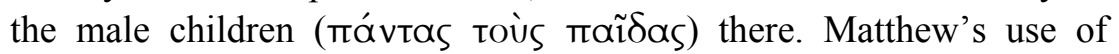
'mocked' ('่vєтaíx $\theta \eta)$ introduces a note of irony when it is seen in the light of its other appearance in 27:29 in the Passion account. Gundry comments, 'There (Matt. 27:29) Jesus the true king of the Jews is mocked; here, Herod the illegitimate king (is mocked). The verb

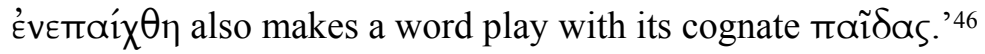

In light of the similarities between the sentences, the introductory Tótє appears to serve more than just an adverbial sequential function between sentences. In each case, the тót $\varepsilon$ introduces a subsection of the pericope in which it is found. This subsection focuses attention on an action by Herod. The fact that this often-used Matthean conjunction appears only twice in these two chapters (apart from its special use in $2: 17$ ) seems to be significant and points to its role as a discourse marker in the entire discourse of the author's Nativity narrative. ${ }^{47}$

\subsection{The Formula Quotations}

Many writers have given attention to the five OT quotations in the Infancy Narrative ${ }^{48}$ The issues raised by Matthew's use of these OT texts - their text form, their hermeneutical implications, the meaning of 'fulfilled', and even what specific OT texts are 'quoted' (e.g. Matt. 2:23) - extend far beyond the scope of this discourse analysis of his

The context here does decide for a more 'official sending' of Herod's henchmen to commit the foul deed.

46 Gundry, Matthew: A Commentary on His Handbook for a Mixed Church under Persecution, 35.

47 Black, 'Historic Present', 135-39. Black calls attention to the similar function of

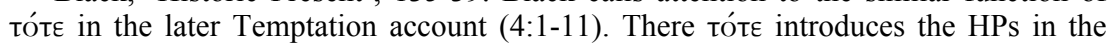
narrative (2:5 - then the devil 'takes'; 2:10 - then Jesus 'says'; and 2:11 - then the devil 'departs'). This later working together of tót $\varepsilon$ with HPs to introduce subsections of a larger section provides parallels with their similar role in Matthew two. She also traces its further use in 26:36-45, the other location in the book where there is a 'peak' consisting of HPs plus tóte's.

48 While commentators and scholarly articles have dealt extensively with the 'formula quotations', the most thorough treatment of all issues related to them is still the published dissertation of George M. Soares Prabhu, The Formula Quotations in the Infancy Narrative of Matthew (Rome: Biblical Institute Press, 1976). See also the excellent treatment by R. T. France, 'The Formula-Quotations of Matthew 2 and the Problem of Communication' in The Right Doctrine from the Wrong Texts?, ed. Greg Beale (Grand Rapids: Baker Books, 1994): 114-34. 
narrative. I will therefore simply attempt to describe the formulae he uses to introduce each quotation while examining their similarities and differences and leave for another discussion those other vital issues. ${ }^{49}$

The quotations are structured in a set formula with some variation. Three are introduced by standard formulae of conjunction + subjunctive which appear quite often in the NT. However, 1:22 and 2:15 contain íva $\pi \lambda \eta \rho \omega \theta \tilde{\eta}$ ('that it may be fulfilled') while $2: 23$ is introduced by ö $\pi \omega \varsigma \pi \lambda \eta \rho \omega \theta \tilde{\eta}$ ('that it may be fulfilled'). In 2:17 the quotation is introduced by the indicative of $\pi \lambda \eta p o ́ \omega$ preceded by tótє.

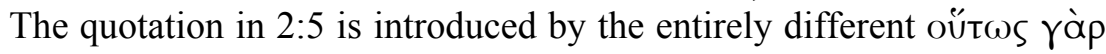
Y'́rpartal ('for thus it is written').

These formula quotations are part of a group of around eleven that appear in Matthew as part of his purpose to show that the things that happened in the life of the Messiah were part of the divine plan beforehand. Outside the Infancy Narrative the expression ivo

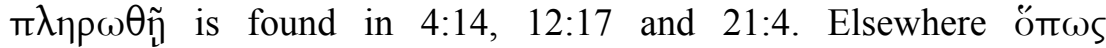
$\pi \lambda \eta \rho \omega \theta \tilde{\eta}$ is found in 8:17 and 13:35. The indicative expression тótє

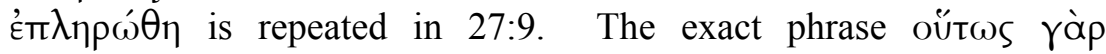
$\gamma^{\prime}$ ' $p \alpha \pi \tau \alpha$ in 2:5 is found only there, but $\gamma^{\prime}$ ' $p \alpha \pi \tau \alpha$ followed by an OT quotation is also found in $4: 4,6,7,10 ; 11: 10 ; 21: 13 ; 26: 24$ and 31 .

One general observation is that all of the formula quotations in the Infancy Narrative are comments by Matthew except 2:5 which is part of the narrative and is spoken by the scribes. It is evident, however, that Matthew intended it to express the divine purpose and not a wrong idea

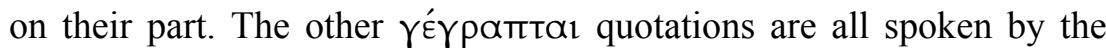
Lord, except the evident misappropriation of the OT by Satan in 4:6.

The differences in the $\pi \lambda$ npó $\omega$ quotations deserve some comment. The unique way in which Matt. 2:23 refers to the settlement of the Holy Family in Nazareth has some characteristics not shared by the

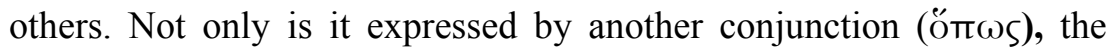
quotation is said to be $\delta i \alpha \grave{\tau} \tilde{\omega} v \pi \rho \circ \varphi \eta \tau \tilde{\omega} v$ ('prophets') and not the singular $\delta ı \grave{\alpha}$ тои̃ трофи́тоu ('prophet') as in the other references. This is undoubtedly an indication that the fulfilment is that of a summary of

49 For a preliminary attempt at classifying the use of these quotations, I suggest that the specific way in which Matthew intended to describe their fulfilment was different for each of them. I suggest for the 1:22, 23 quotation of Isa. 7:14 a Generic Fulfilment; for the 2:5/Micah 5:1 (MT) quotation a Direct Fulfilment; for the 2:15/Hosea 11:1 quotation a Typical/Corporate Fulfilment; for the 2:18/Jer. 31:15 quotation an Analogical Fulfilment; and for the 2:23/? quotations a Summary Fulfilment of the 'netzer' (נצר) passages mentioning the 'Branch' (e.g. Isa. 11:1). 
various unnamed prophecies. While commentators often see Matthew's use of "iva and ö $\pi \omega \varsigma$ as simply 'interchangeable', ${ }^{50}$ Soares Prabhu's explanation for the difference is worth consideration. He bases his conclusions on a comparative study of how Matthew utilises the öm $\omega$ S $\pi \lambda \eta p \omega \theta \tilde{n}$ formulae elsewhere in Matt. 8:17 and 13:35.

The ö $\pi \omega \varsigma$ formulas are found always at the end of large, theologically coherent sections of the Gospel. Mt 8, 17 is attached to a summary which rounds off a collection of miracle stories. Mt 13, 35 similarly concludes a structured collection of parables; and Mt 2, 23 comes at the end of a series of journeys which form the theologically significant itinerary of the child Jesus from Bethlehem to Nazareth. So Mt, it would seem, uses ör $\omega \varsigma$ instead of iv $\alpha$ to introduce quotations placed at the end of collections of pericopes, which have been arranged according to a definite theological pattern, to which the quotation provides the clue. ${ }^{51}$

Finally, the formula quotation of Jer. 31:15 in Matt. 2:17 is slightly different from the others. Unlike the conjunction plus subjunctive pattern, it is introduced by the adverbial conjunction plus the indicative

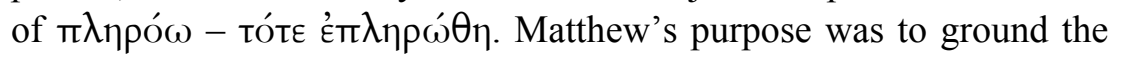
tragic events of the slaughter of the innocents in some kind of understandable theological context, even as he did the other stages in the young Messiah's movements. And yet, he did not use the purpose construction of iva plus subjunctive to do so. The only other place where he uses this formula is when he describes the significance of Judas' betrayal, 'then was fulfilled (тótє є̇ $\pi \eta \eta \rho \dot{\theta} \theta$ ) what was spoken by Jeremiah the prophet' (27:9). In both passages a Jeremiah prophecy is pictured as being 'fulfilled'. Both passages also refer to tragic events - the massacre of the children and the betrayal of Jesus. Could it be that Matthew simply could not bring himself to attribute these awful events directly to the divine will, yet he still sought a meaning for them in OT scripture? ${ }^{52}$ Whatever the reason, it should be noted that this is the type of question that DA asks, rather than settling for the simple answer of stylistic variation.

In regard to the discourse function that these five formula quotations serve, it is important that the quotations are spread throughout the

\footnotetext{
50 W. D. Davies and Dale Allison, Saint Matthew, Vol. 1, 211.

51 Soares Prabhu, The Formula Quotations in the Infancy Narrative of Matthew, 52.

52 As to the question why Jeremiah is mentioned by name whereas the other prophets remain unnamed in the quotations, it could be that since Jeremiah was viewed as the prophet of tragedy par excellence, it would be appropriate if his name were mentioned in connection with these tragic events.
} 
narrative, not haphazardly or at the author's whim, but at specific places to explain every significant event that transpired in the young Messiah's life, both while he was unborn and later in his early years. Hence, they provide cohesion in the overall discourse strategy. Porter defines cohesion as 'grammatical, semantic and contextual factors which hold a discourse together'. ${ }^{53}$

Therefore, by working together with the GAs, the Historic Presents, the tótє and other repeated features these formula quotations provide evidence of a strategy that Matthew employed to communicate a divine design that was at work both implicitly and explicitly in his narrative of the Messiah's early years on earth.

\section{Concluding Observations}

(1) Did Matthew intend to write history, a fiction account or midrash? Although he was not the first to do so, Robert Gundry engendered a good deal of controversy when he wrote in his Matthew commentary that the Matthean Nativity accounts were not intended to be read as history, but that Matthew embellished historical narrative with non-historical elements. ${ }^{54}$ Gundry proposed that Matthew was written in the 'midrashic' manner, in much the same way that the rabbis composed their midrashic commentaries on Scripture. This does not imply that Gundry thought that Matthew never wrote history in his gospel. His observations were applied primarily to the infancy stories and he argued that this approach is consistent with an evangelical view of inspiration. However, the characteristics that we have seen in our analysis of Matthew's language support the position that Matthew intended to write a record of events that actually took place. We should take note of two expressions that Matthew includes in his account where he uses language that explicitly states that certain events in the narrative actually happened. First, three times he records that 'all this

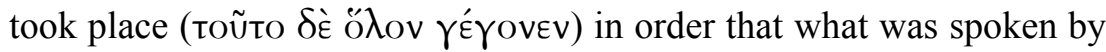
the Lord might be fulfilled' (Matt. 1:22; 21:4; 26:56). Second, on two occasions, which have already been noted, he attaches to his narrative

53 Young, Intermediate NT Greek, 254-55; Porter, Idioms, 304. Porter also mentions 'person reference', 'verbal aspect', 'connectives' and 'informational structure' as other means of holding a discourse together in a unified manner (304-06).

54 Gundry defended his position against his critics in an appendix to the second edition of his commentary (623-40). 
the remark that 'then (то́тє) Scripture was fulfilled' $(2: 17 ; 27: 9)$. In the other formula quotations, these specific phrases are not mentioned, but the implication is that these actual events were indeed a 'fulfilment' of the cited OT passages. Thus, there are good reasons to assert that Matthew intended to relate events that actually transpired in space-time history. ${ }^{55}$ Of course we know that this does not prove that Matthew wrote history, only that he intended to do so. Gundry, however, asserts that Matthew's intention in these chapters was to record these stories in a midrashic style, not as a historian would do in modern times.

(2) Our analysis has also indicated that Matthew wrote his Gospel with an intentional literary design. This well-crafted work militates against any idea of a haphazard patching together of traditions by a redactor. If a redactor did the final work, he did a masterful job. However, he did not do a perfect job since some of the literary seams are not neatly closed and a few matters have been left unrefined. We have noticed that there are many examples of what we could call 'Matthew's broken patterns'. Rather than indicating the work of a redactor, this lack of a stilted, artificial, and 'perfect' framework is evident of an originality rather than a smoothed out redaction. Matthew will not allow us to fit him into our predetermined mold. In other words, Matthew still has left us some surprises that force us to ask why he used a different word or phrase than expected at times. In my opinion, that style only adds to the artistry and the beauty of his composition.

(3) This effort to analyze a unit of biblical literature employing the tools of discourse analysis will hopefully serve as a stimulus for what can be also be done with other genres of biblical literature. Hopefully, the unfamiliarity of some discourse terminology will not put off some scholars from entering this field. DA attends to authorial intent by looking at how an author structures his discourse to communicate his message. Literary critics have been busily using these tools for years. It is time for biblical scholars to step up and expend the same level of energy in analysing biblical discourse. The methodology of DA is one tool that can be helpful in this sacred task.

55 See J. W. Scott, 'Matthew's Intention to Write History', WTJ 47 (1985): 68-82; and P. B. Payne, 'Midrash and History in the Gospels with Special Reference to R. H. Gundry's Matthew' in Gospel Perspectives: Studies in Midrash and Historiography, Vol. III (Sheffield: JSOT Press, 1983): 177-216. 